\title{
An Exploratory Study of the Impact of Government Policies on the Development of Small and Medium Enterprises in Developing Countries:
} The Case of Nigeria

\author{
Olusegun Dosumu, Birmingham City University and Newman University, Birmingham, UK \\ Javed Hussain, Birmingham City University, Birmingham City Business School, Birmingham, UK \\ Hatem El-Gohary, Birmingham City University, Birmingham City Business School, Birmingham, UK
}

\begin{abstract}
This paper explores the effects of government policies on the development of Small and Medium Enterprises in developing countries through the examination of the case of Nigeria. Many research studies reported that SMEs in Nigeria have not benefited from the policies formulated by the government. This paper investigates the impediments to manufacturing SMEs growth and the needed pre-requisite environment for SMEs to benefit from government specific policies. The study adopted a qualitative methodology depending on face to face interviews with 20 SME owners and/or managers in five of the six geographical arears of Nigeria, 20 bank managers in the capital city of Lagos and 20 government officials located in the federal capital city of Abuja. The study unveils unique contextually novel insights, including particularly the distinctive processes and different relationships related to lenders decision. The research findings are consistent with those reported by other scholars in the field, and confirm that government policies and support in the areas of technology, infrastructure and finance affects the performance of SMEs to a great extent in Nigeria.
\end{abstract}

\section{KEYWORDS}

Developing Countries, Government Policy, Nigeria, Small and Medium Enterprises, SMEs Development

\section{INTRODUCTION}

The importance of small and medium enterprises (SMEs) for any country cannot be over-emphasised, but despite their internationally recognised importance, SMEs still face major challenges in many developing and emerging countries (Ayalew \& Gashu, 2015; Eniola, 2014; Fatoki \& Odeyemi, 2010). However, the challenges of business entry, survival and growth are often substantial (Adaramola, 2012). Sequel to this, financial resources and the inability to handle complex business management issues in a complicated and bureaucratic environment present major obstacles. Therefore, the need to improve the different elements that make up a good business climate should be carried out expeditiously (OECD, 2004). 
This article sets out to critically evaluate the effect of government policies in developing the small and medium enterprises (SMEs) in Nigeria, in order to gain an insight into how it affects their business performance. We seek to engage the perspective of the major stakeholders in the development of SMEs which are the government institutions, the banks and the SMEs owner/managers.

\section{LITERATURE REVIEW}

Small and medium enterprises (SMEs) play a very vital role in every economy both in successful developed countries and developing countries (El-Gohary \& El-Gohary, 2016; Khan \& Khalique, 2014; El-Gohary et al., 2013; El-Gohary, 2012a, 2012b, 2011, 2010a, 2010b, 2009; El-Gohary et al., 2009a, 2009b, 2009c; Ariyo, 2008; Wiklund \& Shepherd, 2005; Wong \& Aspinwall, 2004). They perform some important roles like job creation (Farouk \& Saleh, 2011; Deakins et al., 2001; Stanworth \& Purdy, 2004), wealth creation which increases the economy size (Birch et al., 1993). Furthermore, SMEs utilises their limited resources efficiently and develop entrepreneurial skills (Karmel \& Bryon, 2002; NIPC, 2003; Hussain, Millman, \& Matlay, 2006; Poutziouris, 2003; Deakins, Logan, \& Steel, 2001). Studies carried out by various authors, see Matlay and Westhead, (2005); Porter, (2006); Hussain, Millman, and Matlay, (2006); Harvic and Lee, (2002), suggests that SMEs contribute significantly to the social-economy and political infrastructure of developing and developed countries. However, the Nigeria government has been according little attention to this all-important sector for so long despite its numerous benefits (Adjebeng-Asem, 1998).

In the last decade, this trend has changes as the Nigerian government within its capacity is now according all necessary attention to the development of SMEs for accelerated economic growth and empowering its citizen for entrepreneurship and technology innovation (Oyelola, 2013). The major reason for the inadequate attention as suggested by SMEDAN (2011) emanated from the unavailability and paucity of credible and reliable database. This has fraught the major stakeholders to eve sustainable intervention strategies for the development of SMEs in Nigeria (SMEDAN, 2011). As a result of this, it has constrained the government and the policy makers to set an entrenched policy and have a baseline for meaningful comparison (Toby, 2007). This was corroborated by Brevoort and Hannan (2006) in their study that without comprehensive information on SMEs, very little will be known about their contribution to the economy.

In an effort to reposition and create efficient and sustainable SME sector in Nigeria, the government commissioned a collaborated survey report on MSME in 2010 between the national bureau of statistics (NBS) and the small and medium enterprises development agency of Nigeria (SMEDAN). This was one of the concerted responses to the challenges of building a credible and reliable SME database which is a basic requirement to strategically reposition and develop the sector SMEDAN, 2010). Therefore, relevant information will be available and will be useful in grasping the level of contribution of SMEs to the development of the economy (IFC, 2001).

Meanwhile, other factors have been identified constraining the development of this all important sector which includes high production costs emanating from the provision of inadequate infrastructure by the government, inefficient technology use by SMEs relating to processing, preservation and storage of commodities, lack of access to international market, nonexistence of succession plan by the operators, poor access to vital information, inability to keep adequate financial records, and absence of Research and Development to mention a few (Ogbo, \& Nwachukwu, 2012; Obokoh, 2008; Adaramola, 2012; Eniola, 2012). The absence of these facilities has instigated higher overheads cost for the SMEs which has impacted on their profitability and growth because they were responsible to obtain such facilities at their own expense (Mambula, 2002). However, these problems have been on the vanguard of every new government in power to tackle. However, little results have been achieved except the telecommunications sector which is contributing immensely to the development of the economy (Sanusi, 2010; Evbuomwan, et al, 2013). 


\section{Government Policy and Small and Medium Enterprises}

In Nigeria, the recognition of the importance of SME sector has prompted the Government to continue designing and implementing a number of policies and programs to support the development of the sector since independence (NIPC, 2002). The various economic reforms by successive government have been on the horizon since independence in 1960. The benefits of these reforms have not translated into welfare improvements for the citizens because the domestic business activities have not improved due to the significant challenges under the programs (Ojo, 2003; Tumkella, 2003; Mambula, 2002). This has handicapped the SME sector fulfilling its full potential of contribution to the growth and development of the economy from its GDP. However, the economic reforms on SMEs which was introduced as part of World Bank structural adjustment programs is alleged to have a good impact on the development of SMEs (Cook, 1996). This evidence is found in a relatively small number of studies that attempt to measure the impact of economic liberation on the SMEs sector see Boeh-Ocansey, 1994; Dawson, 1994; Steel, 1994; Vachani, 1994; Zake, 1994; World Bank, 1995.

The structural reforms before 2003 were aimed at improving the domestic business climate to enhance business competitiveness by deregulating and reducing government activity in various economic sectors to address various structural constraints to growth. This includes privatization, civil service reform, banking sector reform, and trade policy (Okonjo-Iweala, \& Osafor-Kwaako, 2007). However, some impeding factors in these reforms can be traced to inconsistencies in government policies, poor infrastructures, limited access to finance, disparaging legal and regulatory framework, unavailable support for business development services, ineffective and poorly coordinated institutional support framework, enabling environment, capacity building and corporate governance (Steel \& Webster, 1992; Lightfoot, 1998; Jarvis et al., 1996; Gibb, 1998). Therefore in 2003, the federal government of Nigeria took a big leap by formulating policies for the development of SMEs to address the constraints and to tap the full potential of the sector. The SME Policy takes into account the special constraints and opportunities faced by this sector and aims at strengthening institutions which will address these constraints and maximise exploitation of the opportunities.

This led to the establishment of the Small and Medium Enterprises Development Agency of Nigeria (SMEDAN) vide the small and medium scale industries development agency (establishment) act 2003 with the responsibility of promoting and facilitating the development programs in the SMEs sub-sector. The vision and mission of the agency under the direct supervision of the federal ministry of trade and investment is to establish an efficient SMEs sector that will enhance sustainable economic growth in Nigeria and facilitate the access of SMEs to all the resources required for their development. The agency has the mandate of stimulating, monitoring and coordinating the development of SMEs sub-sector, initiate and articulate policy ideas for SMEs growth and development, reducing poverty, creating jobs, serving as vanguard for rural industrialization and enhanced livelihoods. It is also saddle with the responsibility of linking SMEs to internal and external sources of finance, intermediating between SMEs and government (SMEDAN, 2007).

\section{Government Intervention Programmes to Develop SMEs in Nigeria}

In order to further develop and support the SMEs and other identified sectors of the economy, the Nigerian government changed trend from the classical orthodox method of leaving the allocation of financial resources to the market forces to a developed tailored and direct intervention to support and promote growth in these sectors (Sanusi, 2011). Some of the key interventions in the real sector by the Nigeria government according to Sanusi (2011) includes, the $=\mathrm{N}=200$ Billion Commercial Agricultural Credit Scheme (CACS), the $=\mathrm{N}=300$ Billion Power and Aviation Intervention Fund, the $=\mathrm{N}=200$ Billion Restructuring and Refinancing to the Manufacturing Sector/SME, the $=\mathrm{N}=$ 200 Billion Small and Medium Scale Enterprises Guarantee Scheme (SMEGS), the establishment of Small and Medium Enterprises Developing Agency of Nigeria (SMEDAN) to replicate the duties of small business services in the UK and the small business agency in the USA. 
In addition, the consolidation of banks through merger and acquisition by increasing the capital base of banks from $=\mathrm{N}=2$ billion to a minimum of $=\mathrm{N}=25$ billion. This has reduced the number of banks from 89 to only 24 which have ease bank supervision as a result of the merger. Also, the creation of some agencies like the National Economic Empowerment and Development Strategy (NEEDS) and State Economic Empowerment and Development Strategy (SEEDS), are also some of the measures taken by the Nigerian government to ameliorate the SMEs (Sanusi, 2011). The aim of these schemes is to support the real economy growth by providing long term credit or specialized services to the SMEs as banks only give short term credit. Unfortunately, these schemes often failed to address the problems hampering the development of the SME sector as a result of poor implementation (Eniola \& Etebang, 2015). However, the over reliance of banks on public sector funds is a matter of concern to the government because the private sector is often short changed as a result of the high interest rate paid on bank loans (Soludo, 2004). The public-sector fund is very cheap to the banks even though the motive of government officials to deposit the funds in banks is the unofficial money 'bribe' paid to them. This makes the banks profiteer more on this which makes them expand at the expense of the real economic sectors.

\section{Government Efforts}

Some of the policies and programs identified by Eniola, (2014); Sanusi,(2003); Abdullahi et al. (2015) that has been put in place by different governments in power at various times aimed at promoting SMEs includes the creation of the Small Scale Industries Credit Scheme (SSICS) in 1971, the establishment of Nigerian Bank for Commerce and Industries (NBCI) in 1973, Nigerian Industrial Development Bank (NIDB) in 1964, SME desk in all banks including the CBN, National Economic Reconstruction Fund (NERFUND) 1989, the African Development Bank, the World Bank SME II loan scheme 1990, Nigerian Export Import Bank (NEXIM), Industrial Development Co-ordinating Centre (IDDC), Community Banks, People's Bank, Family Economic Advancement Programme (FEAP), State Ministry of Industry SME Schemes, Small and Medium Industries Equity Investment Scheme (SMIEIS), emerging of Bank of Industry (BOI) in 2002 with the merger of NERFUND and NIDB with mandate of providing credit at $10 \%$ to the industrial sector and SMEs, Small and Medium Enterprises Developing Agency of Nigeria (SMEDAN) and the Credit Guarantee Scheme for SMEs. Others are the fiscal incentives such as tax relief to all new SMEs in their first six years of operation, pioneer status involving non-renewable tax relief for five years and periodic downward adjustment of tariffs to reduce production costs. All these points out that successive government in power since independence have made efforts one way or the other to revamp the SME sector but little success has been achieved.

\section{Research Methodology and Design}

In this study, qualitative method approach was employed for various reasons. Firstly, it will help gain knowledge about emerging issues that can help to understand the effect of government policies towards the development of SMEs (Denzin \& Lincoln, 2005). Secondly, the qualitative method will generate the perspectives of the government agencies involved in the promotion of SMEs, the financial institutions as they are conduit of finance for the development of SMEs through lending and the SMEs owners/managers as well (Creswell, 2003). Thirdly, in-depth interviews and analysis will enable a closer link with the participants thereby capturing their real perceptions with their involvement on the occurrence of events in this context (Sousa and Castro, 2010). Fourthly, it will help to secure rich descriptions of the social world of the SME operations which is valuable in understanding the meanings people have constructed (Easton, 2010). This idea was initiated in order to obtain cross- referencing data and obtain range of opinions from different sources (Cunliffe, 2011). Inputs were solicited from these three stakeholders namely, the government officials, bank officials and SME owners/managers.

The Primary data on the perceptions, thoughts and feelings of the major stakeholders were collected mainly through individual face-to-face, in-depth interviews. All of the interviews took 
place in the various offices of the respondents and were all recorded. The recorded interviews were reviewed and transcribed with NVivo. We identified specific or general issues from the transcriptions which the participants proposed as relevant to the challenges of the development of SMEs. In total, sixty in-depth interviews were conducted with SME owners/managers (20), bank officials (20) and government officials (20). The semi-structured open-ended interview used as the survey instrument was for understanding the rationale behind the effect of various policies towards the development of SMEs (Creswell et al, 2007). We elicited their views by asking broad questions about the various policies they are aware of, how effective the policies are and ideas on how to strengthen the SMEs sector to contribute to the economic growth of the country. The Small and medium enterprises (SMEs) considered in this study were those that fulfilled the criteria of employing between 10 and 199 people according to the definition by (SMEDAN, 2007). Our sampling plan was to get representatives of each of the major stakeholders involved directly with the development of SMEs in Nigeria (Robson and Bennett, 2000).

\section{ANALYSIS AND FINDINGS}

The interviews were first conducted with officials of SMEDAN agency because they have the main responsibility of developing SMEs sector in Nigeria. Then a list of other government agencies with direct or indirect relationship with the growth and development of SMEs were obtained from the agency. The nature of the research was explained to each respondent and confidentiality was guaranteed. Each interview lasted between 45 and 60 minutes and was semi-structured, conducted between January and March 2014. All the interviews were recorded and detailed notes were taken during each meeting and fully transcribed with NVivo. Three main key questions relating to policies and contribution of SMEs to the economy were the main themes of this study. The three questions were asked across board from the three stakeholders identified. Thematic analysis was used to uncover the themes which require further interpretation and involvement of the researcher. This approach helps to identify and describe the issues of policies implementation by the government and its effectiveness towards the development of SMEs in Nigeria through the stakeholders' practical ideas and beliefs. The following key interview questions were asked to address the research questions as a guide to probe into the activities of the various stakeholders involved in the development of SMEs (Smith \& Elger, 2012).

1. Questions informing the respondent perspectives about the policies they will recommend to the government towards the development of SMEs in Nigeria.

2. Questions about the impact the recommended policies will have towards the development of SMEs in Nigeria.

3. Questions eliciting the respondents' perspective on the contributions of SMEs to the economy if these policies are effective.

\section{Theme One}

Policies recommendation. The views of the three stakeholders are almost similar as they all agreed that there are policies in place but the implementation is the major problems. Some of the policies recommended by the bank officials include female entrepreneurship policy targeting women to be empowered and contribute to the household income. Also, young entrepreneurship policy targeting young people to start their own business was suggested which will reduce the social menace in the country such as robbery, kidnapping etc. This is because most of the youths are not engaged in employment. Others are policy that will give room for sectorial allocation for SMEs which will allow special prices for their output and help get their products and services beyond their local environment. Another recommendation by a bank official is that government should formulate import policy 
that will protect the local factories. This will discourage people from importing and help the local factories to be engaged in production hence employing more people. Others are policy on poverty elevation, agricultural loan policy, policy on infrastructure, policy on taxation, technology and policy on manpower. One of the bank officials express further that,

I won't recommend any new policy now but they should implement all the reforms and policies already in existence. If they implement even half of the existing policies, Nigeria will be in a better position. We don't need more policies but we need proper implementation...

The perspectives of government officials and SME owners/managers surprisingly also indicate that there are policies in place but implementing is bad. One of the directors recommended fiscal policy which is needed to boost the SME performance in the country. Other policies can be geared towards capacity building programmes for the SMEs, peer mentoring programme as a strategic to grooming up people, collateral reform and registry where SMEs can access loans from the banks without heavy collateral, policy to boost infrastructure support, policies for fund for women, policy for work space and funding.

Government should review the existing policies to make them friendly. The policies should be harness for people to understand it. People know there are policies but they don't understand those policies. Government should make tax system that is accommodating (Government official, 2013)

One the part of the SME owners/managers, emphasis was laid on one important policy which is privatisation policy. Others are regulatory policy through the financial institutions, SME funding and grant policy, policy to give SMEs loan without collateral and then derive a way of recovering the loan, backward integration policy and tax holiday policy for five years, One SME owners said,

I know that there are policies for fund for women but I tell you the bureaucracy that one undergoes to access such funds is too much. When I was making popcorn, we were made to register with access bank as they have funds for women, but up till now nothing was done for women. They requested for business plans and feasibility studies, and at the end of the day nothing was done. All the energy you put into doing the business plan is too much which I could have used to attend to my business. I will suggest they should remove some of the bottleneck in accessing funds for the Nigerian women...

\section{Theme Two}

Impact of these recommended policies. The banks were of the opinion that it will boost the internally generating income for the economy and increase the number of small business which is the engine room for economy development. It was suggested further that it will impact on the employment rate and government will realise more potentials from the business. This will revamp the SME sector leading to economic growth because more entrepreneurs will emerge which means more jobs for the people. It will also bridge gap between SMEs and large companies which will increase the investment level of the country. One banker explains further that,

If these polices are implemented, Ifeel that the SMEs will grow because they will have easy access to fund, easy access to intellectual knowledge, technical knowhow in place, then the SME will be able to improve their businesses and grow to the next level. These policies should be written as a law. Every government comes in with its own policy and strategy. There is no consistency and it is very rigid making it difficult to change... 
The perspectives of the government officials postulate that SMEs will open up the space and more people will begin to migrate into that sector thereby creating more jobs. This will alleviate poverty and general economic development. Others suggest that SMEs will have large access to market and this will encourage them to produce more and lead to more employment. It was also suggested that it will help to shift focus from oil revenue which has killed innovative capacity of Nigerians and has defocused Nigerian leaders. Furthermore, it will reposition SME Sector, open and increase business and investment opportunities which in turn create access to finance and business development. One government officials said:

Definitely the policies will have a lot of impact on the development of SMEs in Nigeria. I would say that Nigeria is so lucky to have started thinking about the development of SMEs long time ago. We have an agency which is exclusively meant to promote the growth and development of SMEs in Nigeria which is the SMEDAN. They are set up to ensure that they come up with policies and programmes that encourage the growth and development of SMEs. I think they already have a number of incentives for SMES and if the SMEs themselves come together to begin to engage SMEDAN in terms of what their requirements are, it will help SMEDAN to come up with propose policies that will substantially help to address the issues. SMEDAN cannot know what the problems are with SMEs because they are the operators. The contributions from the SME operators themselves will substantially help to broaden policies and improve policy formulation that will help to develop the sector...

\section{Theme Three}

Contribution of SMEs to the Nigerian economy. The SME owners/managers are of the view that apart from turning the economy into a production one rather than being the consuming one will create a lot of jobs for the economy. Other contributions of SMEs according to the owners/manages is that it will galvanise the economy activity in the system by creating employment for the people. Also, there will be less dependent on import because so many goods will be produced within the system, thereby foreign exchange will be properly managed and will not be filtered away. SMEs will contribute to the economy by Job creation and improve skilled labour force which will reduce criminality through gainful employment. One SME owners suggests that:

It will make the economy to grow in the sense that it gives room for other people from other countries to come in and have business and good business relationship with the country which will grow the economy. It will give room for a lot of things to start coming in. When you talk of employment, it will increase the rate of employment. In a nutshell, it will enhance the growth of the Nigerian economy...

The perspective of the bank officials supports the contribution of some other respondents as they suggest it will reduce the social menace like kidnapping, robbery because more people will be highly engaged in employment. There will be enabling environment which will attract foreign investment. Some suggests that it will make the economy more vibrant which will increase the GDP of the country, hence reduce poverty level. This will improve the general wellbeing of the nation and security will improve. One of the bankers said,

I think SMEs can contribute greatly to the economy if these policies are properly implemented and other needed infrastructures are made available to them. Let me tell you example of Dangote who is now known all over the world. He started small and he did not get his funds from the banks but from a rich uncle who helped him to start. That is an example of SMEs becoming something big. The proportion of Dangote contribution to the GDP in Nigeria at the moment is very sizeable but I think SMEs can contribute to the economy of Nigeria. SMEs can create employment opportunity, reduce crime rate and foster the economy of the nation... 
Lastly from the government perspective, it will create a lot of entrepreneurs which will also increase the revenue potentials of the country and provide a lot of employment opportunities. It will also reduce poverty rate in the country in terms of the economic and SME will re-engineer and transform the economy by creating more employment. One government officials said:

If we want to grow our economic sustainably, the way to go is to promote the growth and development of SMEs because they will contribute more than $70 \%$ to the GDP of our various economic. We should be able to encourage our SMEs to specialise. Once they specialise, they will also contribute to earning foreign exchange because when they export their goods or services, they earn foreign exchange for the country and help to increase foreign reserves of the country. These are the contribution SMEs can do once they are given the push...

\section{CONCLUSION}

The study has demonstrated that policy implementation is the major problems with the development of SMEs in Nigeria rather than policy formulation which is in line with the findings of Eniola and Etebang, (2015). Various policies have been formulated in an effort to develop this all-important sector as it is the bedrock of every economy. As demonstrated above, if SME is properly managed, it will create employment. The people who are gainfully employed will pay tax thereby increase the income generation capacity of the nation. It was also identified from the interview that there has been inconsistency in the implementation of government policies for SMEs development due to inadequate data on the operational difficulties of SMEs by the government agencies responsible for the design and implementation of SME development programmes. In most cases, these government agencies do not consider the peculiar nature of the SME operators while designing these policies. This is in line with the findings of Obokoh, (2008) who postulates that the level of education of SME operators is not considered when formulating policies. Hence, the beneficiaries will be unable to benefit from the policies due to their level of understanding.

The conclusions of this study are consistent with the study undertaken by Abdullahi et al (2015) which stressed that the government should provide enabling environment and adequate basic infrastructures in terms of electricity supply, water supply, effective telecommunication system, good road network and better transportation system. This will go a long way to encourage investors to invest more in SMEs and the existing entrepreneurs will use the surplus resources into the operations of their business. Eniola and Entebang, (2015) in their study found that relationship exist between government policies and SME firm performance and have a major impact on the competitiveness of SMEs. This shows that with the right set of policies for SMEs in Nigeria, the sector will contribute a lot to the economy as postulated from the interview. 


\section{REFERENCES}

Abdullahi, M. S., Tahir, I. M., Aliyu, R. L., \& Abubakar, A. (2015). Strengthening Small and Medium Scale Enterprises (SMEs) For Poverty Alleviation in Nigeria. IOSR Journal of Humanities and Social Science, 20(6), $101-110$.

Adaramola, A. O. (2012). Policy Support and Performance of Small and Medium Scale Enterprises in SouthWest Nigeria. European Journal of Business and Management, 4(9), 10-19.

Adjebeng-Asem, S. (1989). Translating Technical Innovation into Entrepreneurship in Nigeria: Social and Policy Implications. Technology Policy and Practice in Africa. IDRC Publications.

Ariyo, D. (2008) Small firms are the Backbone of the Nigerian Economy. Retrieved August 4, 2015 from www. africaeconomyanalysis.org

Ayalew, B. B., \& Gashu, M. (2015). Factors affecting access to finance with reference to micro and small enterprise in Dilla Town, Ethiopia. Journal for Studies in Management and Planning, 1(4), 182-191.

Ayodeji, A. R., \& Balcioglu, H. (2010). Financing industrial development in Nigeria: A case study of the small and medium enterprises in Kwara State. Global Journal of Management and Business Research, 10(3), 46-60.

Birch, D. L., Haggarty, A., \& Parsons, G. (1993). Who Is Creating Jobs? Boston, MA: Cognetics Inc.

Boeh-Ocansey, O. (1994). Small Industries and Structural Adjustment in Ghana. Small Enterprise Development, 6(2), 50-54. doi:10.3362/0957-1329.1995.018

Brevoort, K. B., \& Hannan, T. H. (2006). Commercial Lending and Distance: Evidence from Community Reinvestment Act Data. Journal of Money, Credit and Banking, 38(8), 1991-2012. doi:10.1353/mcb.2007.0000

Cook, P. (1996). The Impact of Structural Adjustment on Small-Scale Enterprises in Developing Countries. UNCTAD, Geneva.

Creswell, J. W. (2003). Research Design: Quantitative, Qualitative and Mixed Method Approaches (2nd ed.). London: Sage Publication.

Creswell, J. W., \& Plano Clark, V. L. (2007). Designing and Conducting Mixed Methods Research. Thousand Oaks: Sage Publications.

Cunliffe, A. L. (2011). Crafting Qualitative Techniques: Morgan and Smircich 30 years on. Organizational Research Methods, 14(4), 647-673. doi:10.1177/1094428110373658

Dawson, J. (1993). Impact of Structural Adjustment on the Small Enterprise Sector: A Comparison of the Ghanaian and Tanzanian Experiences. In A. Helmsing \& T. Kolstee (Eds.), Small Enterprise and Changing Policies: Structural Adjustment Financial Policy and Assistance Programmes in Africa (pp. 71-90). London: IT Publications. doi:10.3362/9781780445908.005

Dawson, J. (1994). Responses to Adjustment - The Marginalization of Small Enterprises in Nigeria. Small Enterprise Development, 5(2), 18-24. doi:10.3362/0957-1329.1994.015

Deakins, D., Logan, D., \& Steel, L. (2001). The Financial Management of the Small Enterprise. London: Certified Accountants Educational Trust.

Denzin, N. K., \& Lincoln, Y. S. (Eds.). (2006). Handbook of Qualitative Research (3rd ed.). Thousand Oaks, California: Sage.

Ekwem, I. (2011). Small and Medium Scale Enterprises Development in Nigeria: Constraints and Policy Options. South Africa: University of Stellenbosch.

El-Gohary, H. (2009). The impact of E-marketing practices on market performance of small business enterprises: an empirical investigation, PhD. Bradford, UK: University of Bradford.

El-Gohary, H. (2010a). Expanding TAM and IDT to understand the adoption of E-Marketing by small business enterprises. International Journal of Customer Relationship Marketing and Management, 1(3), 56-75. doi: $10.4018 /$ jcrmm.2010070105 
El-Gohary, H. (2010b, October). E-Marketing-A literature Review from a Small Businesses perspective. International Journal of Business and Social Science, 1(1), 214-244.

El-Gohary, H. (2011). Electronic Marketing Practises in Developing Countries: The case of Egyptian business enterprises. Germany: VDM Verlag Dr. Müller.

El-Gohary, H. (2012a). Factors affecting E-Marketing adoption and implementation in tourism firms: An empirical investigation of Egyptian small tourism organizations. Tourism Management, 33(5), 1256-1269. doi:10.1016/j.tourman.2011.10.013

El-Gohary, H. (2012b). The impact of E-Marketing Practices on Marketing Performance: A Small Business Enterprises Context. Germany: LAP Lambert Academic Publishing.

El-Gohary, H., Edwards, D., \& Huang, J. (2013). Customer Relationship Management (CRM) Practices by Small Businesses in Developing Economies: A Case Study of Egypt. International Journal of Customer Relationship Marketing and Management, 4(2), 1-20. doi:10.4018/jcrmm.2013040101

El-Gohary, H., \& El-Gohary, Z. (2016). An Attempt to Explore Electronic Marketing Adoption and Implementation Aspects in Developing Countries: The Case of Egypt. International Journal of Customer Relationship Marketing and Management, 7(4), 1-26. doi:10.4018/IJCRMM.2016100101

El-Gohary, H., Trueman, M., \& Fukukawa, K. (2009a). E-marketing and Small Business Enterprises: A Meta Analytic Review. Journal of International Business and Finance, 1(January-June), 42-79.

El-Gohary, H., Trueman, M., \& Fukukawa, K. (2009b). E-marketing and Small Business Enterprises: A review of the literature from 1993 to 1997. International Business \& Technology Review, 160-186.

El-Gohary, H., Trueman, M., \& Fukukawa, K. (2009c). In B. Thomas \& G. Simmons (Eds.), Understanding the factors affecting the adoption of E-Marketing by small business enterprises. In E-Commerce Adoption and Small Business in the Global Marketplace (pp. 237-258). Hershey, PA: IGI Global.

Eniola, A. A. (2014). The role of SME firm performance in Nigeria. Arabian Journal of Business and Management Review, 3(12), 33-47.

Eniola, A. A., \& Entebang, H. (2015). Government Policy and Performance of Small and Medium Business Management. International Journal of Academic Research in Business and Social Sciences, 5(2), 237-248. doi:10.6007/IJARBSS/v5-i2/1481

Etim, E. O. (2010). Promoting small and medium scale enterprises in Nigeria: A panacea for realization of financial system strategy. FSS.

Farouk, A., \& Saleh, M. (2011). An Explanatory Framework for the Growth of Small and Medium Enterprises. In Proceedings of the 29th International Conference of the System Dynamics Society. Washington, DC. USA: The System Dynamics Society.

Fatoki, O., \& Odeyemi, A. (2010). Which New Small and Medium Enterprises in South Africa have Access to Bank Credit. International Journal of Business and Management, 5(10), 128-136. doi:10.5539/ijbm.v5n10p128

Gibb, A. A. (1998, November). Academic Research and the Growth of Ignorance. SME Policy: Mythical Concepts, Myths and Confusions. Paper presented at the National Small Firms Policy and Research Conference, Durham.

Harvic, C., \& Lee, B. (2002). The Role of SMEs in National Economies in East Asia. Cheltenham: Edgware Elgar Publishing Limited.

Hussain, J., Millman, C., \& Matlay, H. (2006). SME Financing in the UK and in China: A Comparative Perspective. Journal of Small Business and Enterprise Development, 13(4), 584-599. doi:10.1108/14626000610705769

IFC International Finance Corporation (SME Department). (2001). Overview of the SME sector in Nigeria. Washington, D.C.

Jarvis, R., Kitching, J., Curran, J., \& Lightfoot, G. (1996). The Financial Management of Small Firms: An Alternative Perspective (Research Report 49). Chartered Association of Certified Accountants.

Karmel, S. M., \& Bryon, J. (2002). A comparison of Small and Medium Sized Enterprises in Europe and in the USA. Routledge. 
Khan, M. W., \& Khalique, M. (2014). An Overview of Small and Medium Enterprises in Malaysia and Pakistan: Past, Present and Future Scenario. Business and Management Horizons, 2(2), 38-49. doi:10.5296/bmh.v2i2.5792

Lightfoot, G. (1998), Financial Management and Small Firm Owner/Managers [PhD Thesis]. Kingston University.

Mambula, C. (2002). Perception of SME Growth and Constraints in Nigeria (Global Perspective). Journal of Small Business Management, 40(1), 58-65. doi:10.1111/1540-627X.00039

Matlay, H., \& Westhead, P. (2005). Virtual Teams and the Rise of E-Entrepreneurship in Europe. International Small Business Journal, 23(3), 279-300. doi:10.1177/0266242605052074

Nigerian Investment Promotion Commission. (2003). Overview of Small and Medium Scale Enterprises in Nigeria (information booklet).

Obokoh, L. O. (2008). Trade liberalization and small and medium sized enterprises (SMEs) failures in Nigeria. Banks and Bank Systems, 3(3), 51-61.

OECD. (2004). Effective Policies for Small Business: A Guide for the Policy Review Process and Strategic Plans for Micro, Small and Medium Enterprise Development. Centre for Private Sector Development. Istanbul: OECD.

Ogbo, A., \& Nwachukwu, A. C. (2012). The Role of Entrepreneurship in Economic Development: The Nigerian Perspective. European Journal of Business and Management, 4(8), 95-105.

Ojo, A. T. (2003). Partnership and Strategic Alliance Effective SME Development. In Small and Medium Enterprises Development and SMIEIS: Effective Implementation Strategies (pp. 185-212). Lagos: CIBN Press Ltd.

Okonjo-Iweala, N., \& Osafor-Kwaako, P. (2007, March). Nigeria's Economic Reforms: Progress and Challenges, Brooking Global Economy and Development (Working Paper No 6).

Oyelola, O. T. (2013). Entrepreneurship for Sustainable Economic Growth in Nigeria. Journal of Sustainable Development Studies, 2(2), 197-215.

Porter, M. E. (2006). The Competitive Advantage of Nations. Basingstoke: Palgrave.

Poutziouris, P., (2003). The Strategic Orientation of Owner-Managers of Small Ventures: Evidence from the UK Small Business Economy. International Journal of Entrepreneurial Behaviour and Research, 9(5), 185-214.

Robson, J. A., \& Bennett, R. J. (2000). SME Growth: The Relationship with Business Advice and External Collaboration. Small Business Economics, 15(3), 193-208. doi:10.1023/A:1008129012953

Sanusi, J. O. (2003, June 10). Overview of Government's Efforts in the development of SME's and the Emergence of Small and Medium Scale Industries Equity Investment Scheme (SMIEIS). Paper presented at the National Summit on SMIEIS organized by the Banker's Committee and Lagos Chamber of Commerce and Industry (LCCI), Lagos, Nigeria.

Sanusi, L.S. (2010). Growth prospects for the Nigerian economy. Convocation lecture by Mr Sanusi Lamido Sanusi, Governor of the Central Bank of Nigeria, at the Igbinedion University Eighth Convocation Ceremony, Okada, Edo State, 26 November 2010.

Sanusi, L. S (2011, March 7). Banks in Nigeria and National Economic Development: A Critical Review (Keynote Address). Proceedings of the Seminar on "Becoming An Economic Driver While Applying Banking Regulations." Canadian High Commission in Joint Collaboration with the Chartered Institute of Bankers of Nigeria (CIBN) and the Royal Bank of Canada (RBC).

Sanusi, L. S. (2013, January 7). Why banks are running away from SMEs. Nation, 8(2364), 32-38.

Saunders, M., Lewis, P., \& Thornhill, A. (2007). Research methods for business students ( $\left.5^{\text {th }} e d.\right)$. London: Prentice Hall.

SMEDAN. (2007), National Policy on Micro, Small, and Medium Enterprises: a background study on main policy for MSME at the regional workshops organised by SMEDAN.

Smith, C., \& Elger, T. (2012). Critical Realism and Interviewing Subjects (Working Paper Series). School of Management, Royal Holloway University of London. 
Soludo, C. C. (2004). Consolidating the Nigerian banking industry to meet the development challenges of the 21st century. In An address delivered to the special meeting of Bankers' Committee-CBN, Abuja.

Sousa, F., \& Castro, L. (2010). Anatomy of relationship significance: A critical realist exploration. In A. Woodside (Ed.), Advances in business marketing and purchasing: Organizational culture, business-to-business relationships, and interfirm networks. Bingley: Emerald. doi:10.1108/S1069-0964(2010)0000016010

Stanworth, J., \& Purdy, D. (2004). Combating Social Exclusion - The Entrepreneurial Dimension. Paper presented at the 27th ISBA Conference, Newcastle/Gateshead

Steel, W. (1993). Analysing Policy Framework for Small Enterprise Development. In A. Helmsing \& T. Kolstee (Eds.), Small Enterprise and Changing Policies: Structural Adjustment, Financial Policy and Assistance Programmes in Africa (pp. 39-49). London: IT Publications. doi:10.3362/9781780445908.003

Steel, W. (1994). Changing the Institutional and Policy Environment for Small Enterprise Development in Africa. Small Enterprise Development, 5(2), 4-9. doi:10.3362/0957-1329.1994.013

Tambunan, T. (2011). The Impacts of Trade Liberalization on Indonesian Small and Medium-sized Enterprises. Trade Knowledge Network Policy Paper. International Institute for Sustainable Development.

Toby, A. J. (2007). Financial management modelling of the performance of Nigerian quoted small and mediumsized enterprises. Journal of Financial Management and Analysis, 20(1), 49-68.

Tumkella, K. (2003, June 10). The Challenge of Globalisation and SME Sector in Nigeria: Repositioning through Technology and Innovation. Paper presented at the National Summit on SMIEIS organised by the Bankers' Committee and Lagos chambers of commerce and Industry (LCCI), Lagos.

Wiklund, J., \& Shepherd, D. (2005). Entrepreneurial orientation and small business performance: A configurational approach. Journal of Business Venturing, 20(1), 71-91. doi:10.1016/j.jbusvent.2004.01.001

Wong, K. Y., \& Aspinwall, E. (2004). Characterizing knowledge management in the small business environment. Journal of Knowledge Management, 8(3), 44-61. doi:10.1108/13673270410541033

World Bank. (1995). Industrial Structures and the Development of Small and Medium Enterprise Linkages: Examples from East Asia (S. Meyanathan Ed.). EDI Series, World Bank.

Zake, J. (1994). Enabling Small Enterprise through Tax Reform in Uganda. Small Enterprise Development, 5(2), 25-31. doi:10.3362/0957-1329.1994.016 